\title{
Hegel Felsefesinde Kötülük Problemi
}

\author{
NAIM SAHIN \\ YRD.DOCCDR, SELÇUK Ü. ILAHIYAT FAKÜLTESI \\ e-mail: nsahin@selcukedu.tr
}

\begin{abstract}
The problem of Evil in Hegel's Philosophy. In the history of thought, one of the problems which make people occupied is evil. In the history of philosophy, many philosophers struggled with that problem. One of those philosophers is G. W. F. Hegel (1770-1831). What is the evil?, What are the natural and human evils? How was the entry of evil into the cosmos? Hegel attempted to answer those questions. According to Hegel, because God is absolute good there is not evil in itself. The evil became after the creation of the cosmos. It vanished through joining of the evil to God. Fundamental offense (sündenfall) was dealt by Hegel in this dimension. In this Hegel's compromised philosophy, there is an important place of the love. All the happening things in the cosmos are the play of God by itself.
\end{abstract}

key words

Hegel, God, The love, Absolute existence, Cosmos, Human, Evil and goodness, Offense, Sin, Paradise, Adam, Eve, Jesus, The son.

Düşünce Tarihi boyunca hem inananlan, hem de her türlü dini inanca karşı çıkanlan meşgul eden kötuilïk problemi, ${ }^{1}$ Tann'nun ilim, irade, kudret ve iyilik sıfatlannın aynı ölçüde savunulamayacağın, bunu savunan her düşünce ve teist sistemin de büyük bir çeliş̧ki içinde olduğu görüşüne götürmüş̧ür. ${ }^{2} \mathrm{Bu}$ problemin çözümünde, kimileri kötülüğün reel varlı̆̆ın görmezlikten gelip onu inkar ederken, kimileri evrende asıl olanın hayır ve iyilik olduğunu, var olan belli nispetteki kötülüğün, estetik yapıyı tamamlamak için bulunduğunu, kimileri de şeylerin ancak zutlan ile bilinebileceğini, bu nedenle de kötülüğ̈̈n iyiliğin zorunlu bir tamamlaycısı olduğunu, dolayssıyla evrende iyinin varolması için mantıken kötünün de bulunması gerektiğini, yine epistemolojiks olarak âlemde iyiliğin bilinip takdir edilebilmesi için, belli miktarda kötülïğün varolması gerektiğinden söz etmişlerdir. ${ }^{3}$

1 Aydın, Mehmet, Din Felseferi, İzmir, 1987, s. 120; Taylan, Necip, İslam Diüsünosinde Din Felsefelen, İst, 1997, s. 97; Taylan, Necip, Dü̧rione Taribinde Tam Sonomu, Ist, 1998, s. 143; Aynca kötülük problemiy le ilgili bilgi için bkz. Yaran, Cafer Sadik, Köailìik ue Theodise, Vadi Yay., Ankara, 1997.

2 Aydın, Mehmet, a.g.e., s. 120.

2 Taylan, Necip, Dürionxe Taribinde Tarm Sonomu, s. 143. 
Bu bağlamda Batı Felsefesi'nde Marks öncesi etik'te iyi ve kötü kavramlan önemli bir konuma sahip olmuş, düşünürler genellikle, iyinin peşinden gitmek, kötüden sakınmak için iyiyle kötü arasındaki fark ortaya koyma çabalanında bulunmuşlardır. Buna yönelik çabalar, Antik ve Hıristiyan etik'inde başlayıp, Aydınlanma Çağı'nun etik'ini aşarak klasik Alman Felsefesi'nin Etik Felsefesi anlayışına ulaşmışır. ${ }^{4}$

Alman Felsefesi Tarihi'nde kötülük problemiyle ilgili kendine has bir görüs ortaya koyan filozoflardan biri de hiç kuşkusuz ki, G.W. Friedrich Hegel (1770-1831)'dir. Acaba bu problemin çözümünde o, nasıl bir yaklaşım sergilemiştir? Ona göre kötü nedir? Kötü diye bir şey var midır? Eğer varsa o, nasl bir varlığa sahiptir ve nasl oldu da bu dünyaya girdi? Onun bu dünyada bir fonksiyonu var mıdır? Varsa nelerdir? Acaba kötülük ortadan kaldınlabilir mi? Nasıl olur da, ilim, irade, kudret ve iyilik sahibi bir Tann ile kötülük bağdaşır? Acaba âlemde görülen gerek tabiat, gerekse insan kaynakls kötülüklerin Tann ile bir ilişkisi var midır? Bu vb. sorulara Hegel Felsefesi'nde nasıl ve ne gibi cevaplar üretilmiş, şimdi kısaca onlan sorgulamaya çalışalım.

Hegel, "kötü"yü iyinin karşitı olarak kabul eder. ${ }^{5}$ Ona göre eğer kötü, iyi olmayan ve kendi başına varlığın devam ettiren bir şey olarak görülürse, o zaman aralanındaki karşıtllğın tanınması gerekir. Kötüyü değişmeyen bir şey olarak görmek yanlş̧ır. Halbuki o, olumsuz bir şeydir. Ve kendi başına hiçbir kalıcllı̆ı yoktur.6 Kötünün "kendinde (an sich)" ve "kendisi için (für sich)" bir amacı yoktur, çünkü o gerçek bir varlığa sahip değildir?

Hegel'e göre iyi ise, "kendinde (an sich)" ve "kendisi için (für sich)"dir, bütün belirlenimlerin özü, hakikat yasası ve dünyanun mutlak son amacıdır. ${ }^{8}$

Tann'y mutlak bir varlik olarak kabul eden Hegel, O'nun bizzat kendi hühümranlığına katılmayı, hayat ve gerçeklik olarak addeder. Yine Hegel, her türlü kötülï̈̆ğ̈, yokluk, gençeksizlik ve varlıksızlık olarak nitelendirir.9 Buna rağmen Hegel, kötünün iyiye karşı olan çelişkisinin de haklı olduğu düşüncesindedir. Ona göre kötüyü olumlu ve kalıcı olarak anlamak yanlıştur, zira kötülük bir olumsuzluktur. ${ }^{10}$ Hegel'in, genel düşüncesine bakıldığında, onun iyi

\footnotetext{
Krumpel, Heinz, Zur Moralphilosophie, VEB Deutscher Verlag der Wissenschaften, Berlin, 1972, s. 74.

Hegel, Ereyklopeadie der philosphisdxen Wissensdxaften III, Frankfurt am Main, 1992 parf. 509, s. 316.

Hegel, Mantzk Bilimi, Cev: Aziz Yardiml, istanbul, 1991, s. 55-56 ek.

Hegel, a.g.e., parf. 510 , s. 316.

Hegel, a.g.e., parf. 507, s. 314.

9 Sass, Hans-Martin, Untersuobrongen zur Religionsphilosophie in der Hegelsdrule (1830-1850), Münster, 1963, s. 212.

10 Hegel, iyi ve kötü kavramun "Wissersdaff der Logik" ve "Phenomenologie de Ceiste" adl eserinde Sein ve Nichts (vartik ve yokluk) ve Unendlichkeit ve Endlichkeit (sonsuzluk ve sonluluk) kavramlanyla da ele almıştır.
} 
ve kötüyü bir noktada uzlaştırmak ve banştırmak istediği görülür. O zaman, acaba bu iki zıtlık, nasıl yapılacak da bir birliğe ve uzlaşmaya götürülebilecektir? Hegel'e göre bu sorulann cevabını şöyle bir çözümlemede bulabiliriz: İyi, kötünün bilgisi olmaksızın var olamaz, başka bir ifadeyle kötü olmadan gerçekten iyinin bilgisine ulaşlamaz. Kötü olumsuzluk olduğuna göre, olumsuzluğun olumsuzluğu da iyidir." Yani kötünün ortaya çıkışı iyinin olumsuzlanmasıyladır. Kötünün ortadan kaldırılması için de tekrar iyinin ortaya çıkması gerekir. Bu da kötünün olumsuzlanması demektir. Dolaysıyla olumsuzun olumsuzlanması iyiliktir.

Bu problemle ilgili olarak Hegel Felsefesi üzerine ciddi araştırmalar yapan Alman düşünürü Ringleben, Hegel'de iyi ve kötünün bu düşünsel ilişkisini şöyle özetlemeye çalışmaktadır:

1) İyi ve kötü karşlukl birbirlenini gerektirir. Biri diğerini zonunlu kalar ve kendini diğeri aracullyla ilişkilendirir.

2) İyi ve kötü; diğerini, kendisinden bir başka olarak ayrmak ve diğerinin ortadan kaldırmasuna bağh olarak, kendisine dayanabilmesi için bizzat zorunluluk arz eder.

3) İyi ve kötüden her biri, diğenini kendine olumsuzlamanın bir momenti olarak zorunlu klar, bunlardan her biri bu özelliği kendinde bulundurur, böylece kendini ve kendi karşıtın kapsar.

4) İyi ve kötünün her biri neticede bir bütündür. Yada bütün her ikisinin aynlmazlı̆̆ıdır. Öyle ki, bu bütün (yani iyi ve kötünün birliktelikleri) momentlerin hareketlerini ortaya koyan, değıstirilemez farklliğı ve çözülemez ilişkiyi içinde barındırur. ${ }^{12}$

Yukanda da ifade ettiğimiz gibi, Hegel'de iyi ve kötü karșllklı olarak birbiriyle ilişki içindedir. Ona göre, iyi ve kötü aynı zamanda özgürlüğün ortaya çıkması için zorunludurlar. Çünkü iyi ve kötünün farkı ortadan kaldınlırsa, bu durumda ahlâki sorumluluk gereği gibi açıklanamaz. Mutlak anlamda iyi, kendisini mutlaklıkta (absolute), mutlak olarak bilen Geist (ruh) in özgürlüğüdür. ${ }^{13}$

Hegel'deki kötülük problemini daha detayl bir şekilde ele alıp ortaya koyabilmek için, onun Tann-âlem ve Tann-insan münasebetinde Tann'ya izafe ettiği sıfatlara kusaca yer vermemiz gerektiğini düşünmekteyiz.

Bu bağlamda Hegel'e göre, Tann soyut bir şey değil, bireysel, kendini düşünen, etkin, canl 14 ${ }^{14}$ dünyanın yaratıcısı, adil ve mutlak iyiliktir. ${ }^{15}$ Eğer

11 Ringleben, Joachim, Hegels Theorie der Sionden de Gnuyter, Berlin, New York, 1976, s. 219.

12 Ringleben, Joachim, a.g.e., s. 221.

13 Ringleben, Joachim, a.g.e., s. 222.

14 Hegel, Vemooft in der Gesdridte (Taribte A kll) Çev: Önay Sözer, İst, 1995, s. 63. 
Tann, boş bir kavram değilse o zaman, mutlak iyi olarak kendisini haber veren bir Tann olmak zorundadır. ${ }^{16}$ Yine onun felsefî teolojisinin temel konusu, bütün duygu, acı ve çelişkilerin çözüldü̈̆̈̈u, ${ }_{17}^{17}$ ebedi hakikat olan ${ }^{18}$ ve bütün varlıkların kaynaklannı aldığı yer olan Tann'dır. ${ }^{19}$

Hegel, mucize, vahiy, yaratma vb. kavramlanı genel dini anlayışın dişında bir yorumlamaya tabi tuttuğu gibi, ${ }^{20}$ adalet kavramın da farklı bir yoruma tabi tutmuştur. "Biz Tann'yı çoğu kez, mutlak güç ve süreç olarak görürüz" diyen Hegel'de adalet; bu güç ve sürecin bir anı (momenti), bir belirliliğidir.21 Bu da bütün sonluların değişmesi ve oluşu, var olmasi ve yok olması, vücuda gelişi ve yok oluşudur. Hegel'e göre, Tann'nun adaleti şunu ifade eder: "Eşya yok olmalıdır. Çünkü onlar olumsuz süreçtir. Bunun için de onlar yokluktur. Dünyanın varluğı gerçek varlık değildir; çünkü dünyada cevher olma özelliği yoktur. Tann'nın adaleti sonlu eşyaya yok olma hakkıı verir. Onlar da yok olmak zorundadır." 22 İşte Hegel'deki adalet kavramı diyalektik bir oluş süreci içerisinde Tanr'nun bir açınımı olarak, sonlu varlı̆ın ortaya çıkması şeklinde anlaşılmalıdır. Bu da bir çeşit mutlak yasanın işleyiş ve etkinliğidir. ${ }^{23}$

Hegel'de sonlu nesnelerin varliğı, sadece görünüs, hatta Tann'nın varlı̆ı yanında bir yokluk mesâbasindedir. Ancak bu yokluğa rağmen dünya var olma hakkına da sahiptir, o bu varoluşunu yaratılma sürecinde gösterir. Bu var ediş ise, Tann'nun mutlak iyiliğidir. Çünkü yaratıcı olmak demek, mutlak iyi olmak demektir, zira hiçbir zaman Tann'da kötülük bulunmaz. ${ }^{24}$

Madem ki, Hegel'de Tann iyidir, o zaman kötülük nasıl oldu da dünyaya girdi? Bir de ona göre, Tann insan bedenine hulul etmiştir; bu anlayışa göre insan tannsal bir tabiata sahiptir. Böyle bir düşünceye sahip olan Hegel için, Hıristiyanlik'taki asli suç (Sündenfall) acaba neyi ifade eder? Tanrısal tabiatlı olan insana bu asli suç nereden gelmektedir? Onun insani yönünden mi, yoksa tannsal yönünden mi? Eğer tanrısal yönden geliyorsa, Tann kötü müdür?

15 Hegel, Vortesumgen Über die Philosophie der Retigion III, Hamburg, 1983, s. 195.

it Schmidt, Erik, Hegels System der Thelogie, Berlin-New York, 1974, s. 40.

17 Hegel, Vortesongen Über die Pbilosophie der Religion I, Hamburg, 1983, s. 3; Hegel, Begnif der Religion, Hamburg, 1925, s. 1.

18 Hegel, Vorlesumgen Über die Pbilosopbie der Redigion I, s. 38.

19 Hegel, a.g.e., s. 29.

20 Bu kavramlarla ilgili bilgi için, bkz. Naim Şahin, Hege''in Tarmss, s. 77,78.

21 Hegel, Vortestongen Über die Pbilosphie der Religion III, s. 195; Hegel, Begrif der Religion, s. 75.

22 Schmidt, Erik, a.g.e., s. 139.

23 Hegel, Vemuafi in der Gesdridte, s. 65-66.

24 Leuze Reinhard, Die A ussendmistlidxen Religion bei Hegd, Gätingen, 1975, s. 173; Schmidr, Erik, a,g.e., s. 139. 
Bu ve benzeri sorulann cevaplann biri doğada meydana gelen tabï kötülükler, diğeri de insanun ahlâki düşüşüne bağh olarak ortaya çıkan kötülükler olmak üzere, iki kısımda ele almaya çalışacağız.

Bunlardan birincisiyle ilgili olarak şu soru aklımıza gelmektedir. Acaba "dünyada meydana gelen tabï kötülükler", mutlak adalet ve iyilik sahibi olan bir Tann'yla bağdaşır mi?

Yukanda ifade ettiğimiz gibi Hegel' göre Tann mutlak iyiliktir. Kötülük ise O'nda, O'nun için olumlu bir şey değildir. Iyyi ile kötü arasındaki aynm Mutlak Fikir'de (Tann) bulunmaz. Zira Tann yegane gerçekliktir, salt iyliktir. O'nun tabiatının özsel birliği iyjliğin ta kendisidir. ${ }^{25}$ Tann kötülüğü istemez, fakat kötülüğ̈ün ortaya çıkış1, Tann'nın dünyayı yaratmasıyla birlikte kendini gösterir. ${ }^{26}$

Hegel'e göre, Tann'nun yaratıcı faaliyetinin ilk ürünü tabiat (Natur)'tır. Tabiat, dini literatürde oğul (sohn) olarak isimlendirilir.27 Fakat Hegel'e göre yaratılan bu tabiat, şuursuz bir varolandır. "Tabiat" diyor Hegel, “Tann'yla doğrudan bir münasebete girmez. Çünkü o, Geist (Tanr)'den hiçbir şey bilmez." 28 Dolayısıyla tabii nesneler hiçbir zaman Tann değildir, ${ }^{29}$ ama Hegel'e göre, bu dünyanun bir anlamı da olmalddır. "Biz" diyor Hegel, "Tann'y dünyanın arkasında değil (Logos'un bir faaliyeti olarak) dünyada aramalıyz. Bütün doğal ve ruhsal dünya Tann'nın bir vahyidir, açlımıdır." 30

O zaman şöyle bir soru akla gelmektedir. Eğer evren Tann'nın bir vahyi, O'nun açılım ise, böyle bir dünyada kötülük bulunabilir mi? Tann mutlak iyilik ise ki, öyle olduğunu belirtmiştik, o zaman iyilikle kötülük, her ikisi birden ayn anda Tanr'da bulunur mu, bulunursa bu takdirde, Tann zitlardan mi meydana gelmistir?

Gerçi yukanda kötülüğün Tann'nın dünyayı yaratmasıyla birlikste ortaya çıktığın ifade etmiştik. Ancak kanumızca buradaki kötülük, tabii kötüliikten daha çok ahlaki kötülïk olarak kabul edilmelidir. Zira onun felsefesinde tabiat kavramının, daha önce dinde (Hristiyanlikta) oğul olarak ifade edildiğinden de söz etmiştik. Buradaki oğul ise, evrende varlığın sürdüren insanı ifade etmektedir.

Birçok teist filozofta olduğu gibi, Hegel'de de (Tann'nun sonsuz iyilik, güç ve adalet olduğundan hareketle) kötülüğün eşyada olması zati değil,

25 Hegel, Vortesungen Über die Pbilosopbie der Religion I, s. 275.

26 Hegeh, 2.g.e., s. 275.

27 Schmidt, Erik, Hegels Systems der Thedogie, s. 40.

28 Schmidt, Erik, Hegeds Leme won Goth, Giaterloh, 1952, s. 219.

29 Reinhart, Leuze a.g.e., s. 177.

30 Schmidt, Erik, a.g.e., s. 157. 
ârizîdir. Ona göre dünyada meydana gelen tabï felaketler, kötülük değil, bir çeşit oluşs sürecinin bir boyutu olarak Tann'ya yükseliş ve katılıştır. Hatta bu Tann'da bir momenttir. "Yer kürenin büyük bir felaketle yok olduğu kabul edilirse" diyor Hegel, "Burada Hiristiyan insanun dünya üzerindeki özgür ruhu etkilenebilir. Ancak olsa olsa bu, yani felaket, dünyanın yokluğu, Tann'ya bir çeşit yüksselmedir." $31 \mathrm{Bu}$ ise bir uzlaşmadır. Fakat bu uzlaşmada Hegel sisteminde "Aş̧" ın önemli bir yer tuttuğunu belirtmemiz gerekir. Zira bütün olaylar, Hegel tarafından Tann olarak da ifade edilen "Aşs" in kendi kendisiyle oyunundan başka bir şey değildir. Hegel'in aşk anlayışında Tann, "Aşk" olarak "ilk"tir, ama aynı zamanda "Son"dur da. Bütün varlıklar bu diyalektiğe tabi olup, "Aşsk"a yani sonuçta tannsal sürece katulırlar.32 Onun felsefesinin bir uzlaşma ve banş̧ma felsefesi olduğu göz önünde bulundurulursa, burada hakiki bir varlığa sahip olmayan kötülïk bu aşk oyununda ortadan kalkacaktur.

Hegel'e göre acaba, tabii felaketlerin alanı olan, bu kâinatın gidişatının ne olacağ 1 ile ilgili bir bilgiye sahip olabilir miyiz?

O, bu konuyla ilgili olarak, "bireyin ve kâinatın gidişatınun ne olacağ1 bilinemez, araştırlamaz. Bu her zaman var olacaktır, fakat ispat edilemeyecektir" demektedir. ${ }^{33}$

Bütün bu tabï kötülüklerle ilgili, Hegel'in açıklamalanndan şunu çıkarabiliriz: Hegel, tabii felaketleri "aşk" anlayışı çerçevesinde ele almakta, her şeyin Tanridan geldiğini sonunda tekrar O'nun hayatuna katılacağın ${ }^{34}$ ve bunun da bir uzlaşma, barışma olduğunu kabul etmektedir. Dolayısıyla tabii felaketlerle gelen acular, ona göre, yine Tanr'da sona erer.

Acaba Hegel'in bu uzlaşma felsefesi yani iyi ile kötü arasındaki ayrliğı kaldırlması, iyi ile kötünün özdeşliği problemine, dolaysıyla bir çeşit panteizme yol açmaz m??

Hegel kendisini, panteist olarak nitelendirenlerin iddialann kabul etmemiş ve kötülük problemini panteizm açısından da yorumlamıştır. Bu konuda, "Spinozacıllk, iyi ile kötünün bir olduğunu iddia ederse, o zaman iyi ile kötü arasındaki aynm da yok olur" diyen Hegel, "böyle bir durumda bütün dinler de yok olur. Eğer her şey Tann olsayd, o zaman Tanrinun var olmadığı, yani yok olduğu iddiası da doğru olurdu. Neticede bütün sonlu olanlar da yok

\footnotetext{
31 Lowith Karl, Gott Mersob sond Welt in der Metaphosik won Descartes bis zu Nietzsche, Göttingen, 1967, s.123

32 Hegel, Vortesunzen Über die Philosoptrie der Religion III, s. 286.

33 Hegel, Vorlesurgen Über die Philosophie der Retigion I, s. 236.

34 Hegel, a.g.e., s. 3; Hegel, Begrif der Religion, s. 2.
} 
olurdu" diyor. ${ }^{35}$ Ç̈̈nkü panteizm ona göre, her şey; kainat, alem, bütün var olanlann hepsi Tann'dır. Zira panteizm, her şeyin Tann olduğunu ileri sürer. ${ }^{36}$ Tann her şeydir, O'nun bu kutu, bu piriz, bu kağıt vs. olması bir panteizmdir, bu ise yanlıștır. Halbuki Tann, Mutlak Ruh (Absolut Geist)'tur,37 Tann iyidir, O'nda kötülük bulunmaz, O, yalnızca iyidir. Iyi ve kötü aynum hiçbir zaman bu Bir'de bulunmaz. ${ }^{38}$

Meseleye ahlâkî kötülük açısından yaklaşırsak, o zaman problemin merkezinde insanı görürüz. Bu problemle ilgili olarak Hegel'in bakış açısı şöyledir:

İnsanda iki belirlenim vardır.

1) Insanin yetenekleri, akl, kendinde ruh (geist)'u, Tann sureti, kendi içinde ve kendinde sahip olduğu tabiat1,

2) İnsanın doğallı̆̆ $\mathrm{ki}$, bu da aklının geliş̧mediği dönemdir. ${ }^{39}$

Ona göre ikinci durumda bir eksiklik söz konusudur. Buradaki eksiklik, insanin kendinde (an sich) akll ve kendinde ruh (geist) olmasidir. Halbuki bu ruh, kendinde ruh olmamal, bilakis kendisi için (für sich) ruh olmalıdır. Buradaki kendinde (an sich)'lik doğalliğın yasasıdır, bu yüzden o yalnuzca tabiattur. ${ }^{40}$

Bundan dolay "insan, tabiat yani fitrat itibariyle iyidir. O, kendinde (an sich) ruhtur ve Tann'nun bir numûnesi olarak yaratulmıştur. Tann iyidir ve insan da Tann'y yansıttığına göre Tann'nın aynası olarak iyidir. Buna göre, insan kendinde iyidir. Fakat "kendinde" kavramı tek yönlüdür ve her şey söylenmemiştir. Çünkü Mutlak Kavram'la birlikte olduğu ve ayrilma (yani dünyanun yaratılması) da olmadığı için insanun varlığı hala kavramıdır. Burada insanın tabiat itibariyle iyi olduğu söydenebilirse de, aslında Hegel'e göre iyi değildir, çünkü o, henüz olması gerektiği gibi değildir. ${ }^{41}$

Hegel konuyla ilgili olarak burada genel ilk günah (Sündenfall) anlayışından ayrularak şöyle bir açıklama yapar, "mesela çocuklar kötü değildir, suçsuzdur. Hatta onlar irade sahibi olmadıklanndan temyiz yeteneğine de sahip değillerdir. Ancak kötüye ait karar verme yeteneğine, iradeye sahip olmak ve davranışların doğasını kavrayabilecek potansiyele sahiptir. ${ }^{42} \mathrm{O}$ halde, Hegel'e

35 Hegel, Vorlesungen Über die Philosophie der Religion I, s. 275.

36 Hegel, Begrif der Religion, s. 195.

37 Hegel, a.g.e., s. 197; Hegel, Voteswongen Über die Philosoptie der Religion I, s. 322.

38 Hegel, Vortesungen Über die Pbilosopbie der Religion III, s. 225.

39 Hegel, Voteswongen Über die Pbilorqphie der Religion III, s. 134.

to Hegel, a.g.e., s. 134.

41 Hegel, a.g.e., s. 135.

42 Hegel, a.g.e., s. 135. 
göre, kötünün ortaya çıkması için insanda irade ve temyiz gücünün oluşması gerekmektedir. Gerçi onda irade insanun büyümesiyle geliştiği sürece o, kötüden ziyade iyiyi isteyen bir keyfilik olarak gözükür. Ona göre çocukluk bir çeşit suçsuzluk durumudur. İşte insan çocuk gibi olmamalı ve bu anlamda suçsuz da olmamalıdır. Yani insan böyle bir durumda kalmamalidır. ${ }^{43}$

Diğer taraftan ise insan, ikinci durumdan kurtulmuş, karar veren irade sahibi bir varlık, yani "kendisi için (für sich)" olmuştur. Bu bir tannsal zorunluluktur. Insan mutlak kavramdan aynlmış, "kendisi için" olmuş ve kendi iradesine tabi olmuştur. İşte o, kendi iradesi nazannda kötüdür. Insan burada ruh olarak özgürdür. Kötülük işte burada yerleşmiştir, burası kötülüklerin kaynağı ama uzlaşmanın da olduğu son noktadır. ${ }^{44} \mathrm{Bu}$ da Hegel'in çift yönlü kullandığ 1 "tabiat" kavramının ikinci yanın teşkil eder. ${ }^{45}$

Hegel'in çift yönlï olarak kullandığı tabiat kavram, bir paradoks gibi görülüyorsa da tabiattan iyi olmasından kastı insanun kavram olarak, Tann kavraminda bulunmasını; ikinci olarak tabiattan kötü olmasın da insanın yaratılmasıyla meydana gelen, maddesel yönüne bağlamaktadır.

Iyiyle kötünün tanınp bilinmesi Hegel'e göre, ahlaki terbiyenin başlangıcıdır.46 $\mathrm{O}$, -daha önce de belirttiğimiz gibi- Tann her şeydir, anlamindaki Spinozaculğı reddeder. "Eğer Tann her şeydir denilirse", diyor Hegel, "o zaman iyi ile kötü bir olur ve aralannda hiçbir fark kalmaz. Gerçekte her şey Tann olsaydı, Tann ortadan kalkand. Dolayssıla ahlaklılik da ortadan kalkard.." 47

Hegel, yukandaki meseleyi yaratulş̧ sürecine göre yorumlar. Ona göre, Tann, insanı kendi biçimine (suret) göre yaratmıs ve onu Cennet'e koymuştur. Yllan Âdem ve Havva'yı, Tann'yła eşit olacağı yalanıyła yasak ağaçtan yedirtmiştir. Ve onlar da suç işlemişlerdir. ${ }^{48} \mathrm{Hegel}$, Incil'de anlatılan bu yaratulş̧ hikayesini öz itibariyle kabul etmekle beraber yllanun yalan söylemediğini, aksine yllana bu görevi Tann'nun verdiğini söyler. ${ }^{49}$ Böylece bu ağaç bir çeşit iyiyle kötünün idrakinin ağacı olmuştur. 50 Onlar da bu yasaya aykın davrandıklan için, Tann tarafından Cennet'ten uzaklaşturlarak cezalandınlmışlar. Bu

\footnotetext{
43 Hegel, a.g.e., s. 135.

44 Hegel, a.g.e., s. 138.

45 Hegel, a.g.e., s. 221.

46 Müler, Gustav E., Hegd Über Offenbanong Käde zond Pbilosopbie, München, 1939, s. 28.

4) Hegel, Vorlesingen Über die Philosqbie der Religion I, s. 275.

48 Hegel, Vortesungen Über die Philosqbie der Religion III, s. 139.

49 Hegel, a.g.e., s. 139.

so Hegel, a.g.e., s. 221
} 
nedenle de ilk sonlu ve ilk ölümlü olmuşlardır.51 Bu yasak ağaçtan yemedeki esas mana, içinde günahın bulunmasıdır.52 O zaman Âdem ve Havva'nun Cennet'ten kovulması Cennet'in kaybı demektir. Bu da ilk günah (Sündenfall) denilen şeydir. ${ }^{53}$ İnsan bu ayrilkkta kendisi için, varlık, şuur, öz bilinç, sonsuz öz bilinç olduğunu bilir ve böylece ruh (Geist) olarak yüce saygınlı̆ga ulaşır..$^{54}$ İşte Hegel beşeri kötülïğg̈ insan iradesine bağlamak suretiyle Tann'nun kötülüğün kaynağı olamayacağını söyler . Ona göre Tann'da kötülük yoktur. Kötünün olumlu bir şey olduğu ve bu olumluluğun Tanrida olduğu söylenemez. ${ }^{55}$ Burada şöyle bir soru akla gelebilir: Yasak ağaçtan yeme işini gerçekleştiren Âdem ile Havva olduğuna göre, bu suç (asli günah) nasıl oldu da diğer insanlara geçti?

Hegel bu soruya şöyle açıklık getirmektedir. Ona göre genel insan, ilk insan olarak tasavvur edilirse, diğerlerinden farkl tasavvur edilmelidir. Ilk insan mutlak ilk kavramına göre ilk insandır. Böylece o, insanlığın genel şuurudur. Böyle olunca suç yalnuz, Âdem ve Havva'nun değil, Âdem ve Havva'nun altında yatan tümel insan kavramunun ait olduğu bütün insanların suçudur. Asli suç böyle anlaşılmalıdır. ${ }^{66}$ Dolaysıyła $\mathrm{Hz}$. Âdem'e verilen irade özgürlüğü bütün insanlara da verilmiştir. Iş̧te kötülük ve suç bu irade özgürlüğ̈̈ne sahip olan insana aittir, yoksa Tanriya değil.

Yine ylan Âdeme yasak ağaçtan yedirdiğinde, aslında bu sadece Âdem değil, Âdem isminin altundaki ikinci bir Âdem olmasıdır ki, bu da Hegel'e göre İsa'dır. ${ }^{57}$

Asli suça bu şekilde bir açlklama getiren Hegel, Tann'yła birliğin sağlanması için de şu açıklamalan yapar. "İyi ile kötünün kaynağı insan idrakine bağlıdır." 58 İste bu idrak insanı hem ölümsüz yapar hem de Tann'yla birliği sağlar, ona göre eğer insan düşünen ve hisseden olarak, tannsal ve insani tabiatın kendinde varolan birliğini bilirse o zaman uzlaşmanın, imkanlan da var demektir. Bu durumda insan, bu bilgiyle Tanr'ya yükseldiğini bilebilir. tannsal ve insani ruhun birliği, insanda nesnel tarzda gösterilmelidir. Bu da ancak Tann'nın insanlaşmasıyla olur, böylece Tann'yla insan birliği zorunlu bir esas olmuş olur. ${ }^{59}$

\footnotetext{
Hegel, a.g.e., s. 42.

Hegel, a.g.e., s. 225.

3 Müler, Gustav E., a.g.e., s. 28.

Hegeh, a.g.e., s. 140.

55 Hegel, a.g.e., s. 275.

s6 Hegel, a.g.e., s. 225.

57 Hegel, a.g.e., s. 139.

58 Hegel, a.g.e., s. 225.

59 Hegel, a.g.e., s. 236.
} 
Hegel'in kötülükle ilgili görüşlerinin bir takım eleştirilere konu olduğunu görmekteyiz. Bunlardan bazılan şunlardır:

1) Hegel dünyada kötünün gücünü yanlş tanımıss, günahun gücünü kendinde yeterince kavrayamamış ve bu yüzden de uygun bir dünya görüşü oluşturamamıstur.

2) O, kötüyü ahlaksal ilişkiden soyutlamıs ve genel karakterin bir kavramu haline getirmiştir.

3) Hegel'in günah kavramı intellektüeldir, günah iradenin değil de, düşüncenin bir işiymiş, mantuksal bir zorunlulukmuş ve kişisel bir suç değilmiş gibi ele alınmıştur.

4) Hegel olumsuz olanı kavramış, ancak bunu nihai birliğin mükemmelliğine ait bir şey olarak kavramuştur. 60

Yukandaki eleştirilere aslinda Hegel'in Hristiyanlik inancı etrafinda cevaplar verdiğini ifade eden Alman düşünürü $\mathrm{E}$. Schmidt, "Hegel dünyanın acıları ve kötülükleri konusunda çekimserdi ama aym zamanda dünyanın acılan ve kötïlükleriyle uğraşmıştr" en önemli meselesidir"62 sözüne de işaret eden Schmidt, "Hegel, derin bir dini hayata sahipti" 63 diyor. Gençekten de Hegel'in kötülük problemiyle ilgili optimist dünya görüsüü̈ü arka planunda, onun Din Felsefesi göz önüne alındığında Hristiyanlık'ın önemli bir yeri vardır.

Ģinkü insanun kötrïlüklerden armup Tann'yla birleşmesi "kultus (dini işler)"ta olur. Ona göre kultus; insanın Tann'yla birleşmesi, kendini Tann'da ve Tann'nun da kendisinde olduğunu bilmesidir. Ona göre böyle bir durum En Yüce Mutlak lezzetin bir ifadesidir. ${ }^{64}$

"Nasıl ki, insanun davranıslannndan sorumlu olabilmesi için hür olması gerekiyorsa" diyor Hegel, "dinde, dolaysıyla onun bir parçası olan kultus'ta da hür olması gerekir. Özgürlük insanın sahip olduğu en yüce kavramdır. Zira dinde insan Tann önünde, kendi iradesini ilahi olana uygun yaparak Yüce İrade'ye karşı koymaz. İnsan hürdür ve kultus'ta birliğe ulaşrr. ${ }^{65}$

Dinin irade ve duygulann üzerinde kalpleri tevazu ile doldurması gerektiğine inanan Hegel, bu dinin ahlâka ve onun gerekçelerine yüce bir canlluk vermesi gerektiğini söylemesib6 onun dindar bir hristiyan olduğunun kanııdır

\footnotetext{
6o Schmidt, Erik, Hegeds Ledre zon Gat, s. 201.

61 Schmidr, Erik, a.g.e., s. 201.

62 Nohl, Hermann, Hegeds Thedogische Jugendsdmiften, Frankfurt/Main, Tübingen, 1907, s. 3.

63 Schmidt, Erik, a.g.e., s. 18.

64 Hegel, Vortes angen Uber die Pbilospobie der Religion I, s. 331.

65 Hegel, Vortesugen Über die Pbilosophie der Religion III, s. 339.

66 Nicolin, Friedrich, Hegd (1770-1970) Leben Werke Wrkurg, Sturtgart, 1970, s. 90-91.
} 
diyebiliriz. Zaten onun genel felsefesi, Hristiyanllk'ı rasyonel bir zemine oturtma çabasıdır.

Öyle ki, Hegel'de Tann'ya karşı yaplan duanın önemli bir yeri vardır. Ona göre dua, kalbin kendinde ve kendisi için "Aşk" olan Mutlak'a yükseliştir. Duanın kendisi ifa, istek ve rahmettir. Dua dilinde tasavvur, Tann'y kişi olarak görür ve onun için Tann, seven gerçek baba olur.67 Ibadetler de subjektif öz bilinçtir. İbadet pratik ilişki olarak ortaya çıkar. İbadetlerde inanç ortaya çıkar, inanç ise aracilktır, Tann'nın yani Mutlak İde'nin bilinmesidir.68

Ringleben de Hegel felsefesinin Tann'nun Mutlak iyi varlğın kötü faktörüyle dengeleme çabası verdiğini, kötünün tanınarak onun Tann'nun gücü ve kutsalliğıyla çeliş̧kisini uzlaştırdığım söylemektedir. ${ }^{69}$

Aslinda Hegel dünya görüşünde bașta Tann-alem dualizmini ve bütün zıtlkklan aşmak ister. $\mathrm{O}$, bu tavnyla mistik bir yapıya da sahiptir diyebiliriz. Çünkü ona göre, Mutlak Ruh'la doğanın (baba ile oğul) birliği, Aşs ve Ruh (Geist)'tur. Bu da Tann'nun kendisidir.70 Ona göre, insan için en son amaç, Aşk olan Tann olmalidır. ${ }^{71}$ İste bu amaç, kötünün yokluk olduğu en yüce bir ahlaklllkktr. Bu nedenle insan bu farklliğın, bu yokluğun kendinde gerçekleşmesine izin vermemeli ve kendinde geçerli kulmamalidır. Eğer insan, bu ayrımı Tann'nun karşısına koyarak kendinde ve kendisi için genel bir yaklaşım olarak kabul ederse, o zaman kötü olur.72 Insan bu aynmu yok sayp, kendi varoluşunu sadece Tann'ya ve O'nun yoluna yönlendirirse bu durumda da iyi olur. Bu farkllik insanda olmasına karşllk Tann'da bulunmaz. ${ }^{73}$

Sonuç olarak acaba Hegel -yukandaki açıklamalarına da bakarak- kötünün Tann'yla olan ilişkisini tam olarak çözmüş müdür? Bu soruya evet demek pek mümkün gözükmemektedir. Bununla beraber o, kötülüğ̈̈n Tann'da olmadığıı, ancak Tann'nun dünyayı ve insanı yaratmakla beraber kötünün ortaya çıktığını vurgulamaya çalışmıştır.

Bu düşünceler doğrultusunda acaba Tann kötünün kaynağına doğrudan katımış mı oluyor? Doğrusu Hegel bu soruyu da net bir şekilde cevaplamı-

67 Dulckeit, Gerhart,Die Idæe Gattes Im Geiste der PhilosophieHegeds, München, 1947, s. 68.

68 Hegel, Vontes romen Über die Philosphise der Religion I, s. 238.

69 Ringleben, Joachim, a.g.e., s. 202.

70 Hegeh, a.g.e., s. 286.

71 Hegel, a.g.e., s. 276.

72 Hegel, a.g.e., s. 276.

73 Hegel, a.g.e., s. 276.

74 Hegel, Wissenschafi der Logik I, Leibzig 1951, s. 69; aynca bkz. Wollgast, Siegfried, "Zu Hegels Auffassung von Mistyk und Pantheismus" Wissersdxaftidbe Zeisdonift 21. Jalmgang Heft I,FriedrichSchiller-Üniversitaet Jena, 1972, s. 320-321. 
yor. Ancak o, "denk olmayanın denk olmayandan ortaya çıkmasını aynı ölçüde zayff bir ihtimal" olarak görmektedir. "Zira eğer zayff olandan güçlü olan veya küçük olandan büyük olan veya kötü olandan iyi olan veya tam tersine iyi olandan kötü olan doğsa, o zaman varolmayan varolandan ortaya çıkardı ki, bu imkansızdir, o halde Tann ebedidir"74 demektedir.

Acaba Mutlak Geist olarak Tann, her şeyi kapsıyor ve kuşatıyorsa, o zaman emprik bir gerçeklik olarak bu evrene dahil olmuş mudur? Hegel'in bu soruya cevabı da açık ve anlaşlır değildir. Zira Tann, Mutlak Geist olarak Evren Geist (Weltgeist)'i olur, ama yetkinliğinden bir şey kaybetmez. Ancak bu da, -burada değinilmesi uzun konu olduğundan bir başka çalışmada ele alınması gereken- bir takım problemleri beraberinde getirmektedir.

Netice itibariyle Hegel, Tanr'dan kötüyü ayırmak ve kötünün kaynağtnun insanın özgür iradesine bağlamakla yetinmiş ve daha doğrusu kilisenin öteden beri yaptığını yapmaya çalışmıstır.

\section{Bibliyografya}

- G.W.F, Hegel, Begrif der Religion, hrsg. G. Lason, Verlag Felix Meiner, Hamburg, 1925

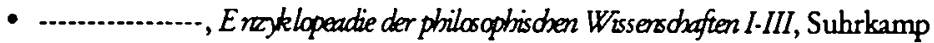

Taschenbuch Wissenschaft, Frankfurt am Main, I,III,1992 ; II,1993.

- - -

- .......-...-......, Vortesungen Über die Philosphie der Redigion I-III, hrsg. Walter Jaeschke,

Verlag Felix Meiner, Hamburg, 1983.

- ------.-.-.--., Vemogft in der Gesdhidhte (Taribte Akıl), Çev: Önay Sözer, Kabala Yay., İstanbul, 1995.

- -..-.-.-.-, Wissersdxafi der Logik I, Leibzig, 1951.

- Aydin, Mehmet, Din Fessefesi D.E.Yay., İzmir, 1987.

- Dulckeit, Gerhart, Die Idee Gottes, Im Geiste der Philosophie Hegels, Verlag Hermann Rinn, München, 1947.

- Krumpel, Heinz, Zur Moralphilosophie, VEB Deutscher Verlag der Wissenschaften, Berlin, 1972.

- Leuze, Reinhard, Die Asosendmistlichen Religion bei Hegel, Vandenhoeck Ruprecht, Göttingen, 1975.

- Löwith, Karh, Gatt Mensds und Welt in der Metaphossik zon Descartes bis zu Nietzsde, Vandenhoeck Ruprecht Göttingen, 1967.

- Müler, Gustav E., Hegel Uber Offenbanong Konde zond Philosophie, Verlag Ernst Reinhart, München, 1939.

- Nicolin, Friedrich, Hegel (1770 1970) Leben-Wenke Wrakrong, Verlag Ernst Klett, Sturtgart, 1970.

- Nohl, Hermann, Hegels Theologisde Jugentsdriffer, Minevra Gmblt, Frankfurt / Main, Tübingen, 1907. 
- Ringleben, Joachim, Hegels Theorie der Sïnden, de Gruyter, Berlin, New York, 1976.

- Sass, Hans-Martin, Untersudrongen zur Religionsphilosophie in der Hegedsdrule (1830-1850), Münster, 1963.

- Schmidr, Heinrich, Philosophisdes Wöntertad, Alfred Kröner Verlag, Sturtgart, 1991.

- Schmidt, Erik, Hegels Ledre zon Got, Verlag C. Bertelsmann, Gütersloh, 1952.

- ....-....-......, Hegels System der Thelogie, Walter de Gruyter, Berlin, New York, 1974.

- Sahin, Naim, Hegel'in Tamss Çizgi Kitapevi, Konya, 2001.

- Taylan, Necip, Islam Düsionos inde Din Fedsefeleri, Ifav, Istanbul, 1997.

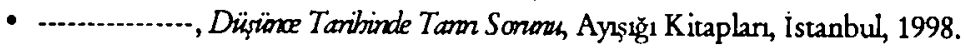

- Wollgast, Siegfried, "Zu Hegels Auffassumg zon Mistok und Pantheismo", Wissenschafuliche Zeitschrift, 21. Jahrgang, Heft I, 1972, Geselschafts- und Sprachwissenschaftliche Reiche, Hegel und die Französische Revolution, Friedrich-Schiller-Ünivesitaet Jena, 1972.

- Yaran, Cafer Sadik, Körillïk ue Theodise, Vadi Yay., Ankara, 1997. 